\title{
Evaluation of Oxidative Status in Acetaminophen-Treated Rat Hepatocytes in Culture
}

\author{
T. ROUŠAR ${ }^{1,2}$, O. KUČERA ${ }^{1}$, P. KŘIVÁKOVÁ ${ }^{1}$, H. LOTKOVÁ ${ }^{1}$, R. KANĎÁR ${ }^{2}$, \\ V. MUŽÁKOVÁ ${ }^{2}$, Z. ČERVINKOVÁ ${ }^{1}$ \\ ${ }^{1}$ Department of Physiology, Faculty of Medicine in Hradec Králové, Charles University, \\ ${ }^{2}$ Department of Biological and Biochemical Sciences, Faculty of Chemical Technology, University \\ of Pardubice, Czech Republic
}

Received October 26, 2007

Accepted January 18, 2008

On-line April 1, 2008

\section{Summary}

The present study describes the estimation of acetaminophen (AAP) toxicity in cultured rat hepatocytes. We used different concentrations of AAP $-1,2.5,5,10$ and $20 \mathrm{mM}$, to test influence of AAP on cellular viability, functional capacity and oxidative status at given time intervals. WST-1 test showed decrease of dehydrogenase activity in 5, 10 and $20 \mathrm{mM}$ AAP to $75 \%$ of control values after 1 hour of incubation. At $12 \mathrm{~h}$ of treatment, all AAP concentrations decreased WST-1 signal; no enzyme activity was found since $18 \mathrm{~h}$ in cells treated with $20 \mathrm{mM}$ AAP according to LDH leakage test performed at $24 \mathrm{~h}$ of incubation. Functional capacity was tested by albumin assay where the decrease was strictly related to AAP dose. Intracellular oxidative status was assessed by analysis of GSH/GSSG levels and time course of ROS production and glutathione reductase (GR) activity. Increased ROS production was found already after $3 \mathrm{~h}$ of incubation in 2.5, 5, 10 and $20 \mathrm{mM} \mathrm{AAP}$, respectively. The highest ROS production was measured after $12 \mathrm{~h}$ treatment. GR activity was decreased already after $3 \mathrm{~h}$ of incubation and remained also decreased in cells treated with 2.5, 5, 10 and 20 mM AAP during further incubation.

\section{Key words}

Acetaminophen - Cultured hepatocytes - Hepatotoxicity • Glutathione • ROS

\section{Corresponding author}

T. Roušar, Department of Physiology, Faculty of Medicine in Hradec Králové, Charles University in Prague, Šimkova 870, 50038 Hradec Králové, Czech Republic. E-mail: Tomas.Rousar@upce.cz

\section{Introduction}

Acetaminophen overdose is the most frequent cause of drug-induced acute liver failure in men (James et al. 2003, Lee 2003). It causes typical centrilobular necrosis in the liver, described in detail by Mitchell et al. (1973a). Acetaminophen (AAP) is metabolized to major extent by conjugation with glucuronic and sulfuric acid in the liver. The remaining part is metabolized by different isoenzymes of cytochrome P450 to active metabolites (Jaeschke and Bajt 2006), presumably to $\mathrm{N}$-acetyl-p-benzoquinone imine (NAPQI). NAPQI is detoxified by glutathione (GSH) to form glutathionyl conjugate. After the cellular glutathione stores are depleted, NAPQI binds to $\mathrm{SH}-$ moieties of proteins within the cell (Mitchell et al. 1973b). Consequently, there have been found many mechanisms contributing to the cell death - impairment of mitochondrial respiration, induction of oxidative stress and lipoperoxidation. In addition, the opening of mitochondrial permeability transition pore due to AAP treatment was described recently (Kon et al. 2004). The various mechanisms proceeding during the injury are described in detail in numerous current reviews (Jaeschke and Bajt 2006, Jaeschke et al. 2003, James et al. 2003). Despite substantial progress in our understanding, some mechanisms of the acetaminopheninduced liver injury remain still unknown.

It is generally accepted that AAP-injury is related with oxidative stress. The primary cause of oxidative stress is a decrease of intracellular GSH levels 
due to the conjugation of GSH with NAPQI and an increase of glutathione disulfide (GSSG) levels (Mitchell et al. 1973b, Knight et al. 2001). In addition, it was proved that the reactive oxygen species (ROS) are produced as a consequence of decreased levels of GSH after administration of acetaminophen in hepatocytes (Bajt et al. 2004).

The acetaminophen toxicity was firstly studied in in vivo experiments in mouse and rat models (Jollow et al. 1973, Mitchell et al. 1973a). Consequently, in vitro studies have been used to estimate of AAP toxicity and recently, both types of experiments are used for characterization of mechanisms involved in AAP toxicity (Bajt et al. 2004, Kon et al. 2004, Reid et al. 2005). Since large variation in acting of different AAP concentrations has been reported, the aim of our study was to describe detailed mechanisms of injury in cultured rat hepatocytes under different AAP concentrations. We focused mainly on the investigation of oxidative status in hepatocytes, especially using intracellular ROS probes.

\section{Methods}

\section{Chemicals}

Medium Williams' E (without phenol red), fetal bovine serum, penicillin, streptomycin and glutamine were purchased from PAN BIOTECH GmbH (Germany). Collagenase cruda was obtained from SEVAC (Czech Republic), insulin (Actrapid, Hoechst, Germany), glucagon (Novo Nordisk, Denmark), prednisolon (SoluDecortin, Merck, USA), Rat Albumin ELISA Quantification Kit (Bethyl Lab. Inc., USA), Cell Proliferation Reagent WST-1 (Roche, Germany) and CM-DCFDA (Molecular Probes, USA). Type I collagen, trypan blue, kit for lactate dehydrogenase (Diagnostic Systems, Germany) and all other chemicals, if not specified in the article, were purchased from SigmaAldrich (USA).

\section{Animals}

Male albino Wistar rats (Biotest, Czech Republic) were housed at $23 \pm 1{ }^{\circ} \mathrm{C}, 55 \pm 10 \%$ relative humidity, air exchange 12-14 times/h, and 12-hour lightdark cycle periods $(6: 00 \mathrm{~h}$ to $18: 00 \mathrm{~h})$. The animals had free access to standard laboratory rat chow (DOS 2B, Velaz, Czech Republic) and tap water. All animals received care according to the guidelines set by the Institutional Animal Use and Care Committee of the Charles University, Prague, Czech Republic.

\section{Hepatocyte isolation, cultivation and treatment}

Hepatocytes were isolated from rats with a body mass of 220-250 $\mathrm{g}$ by collagenase perfusion (Berry et al. 1991). The viability of freshly isolated hepatocytes was more than $90 \%$ as confirmed by trypan blue exclusion. Isolated hepatocytes were suspended in Williams' E medium supplemented with fetal bovine serum (6\%), glutamine $(2 \mathrm{mM})$, penicillin $(100 \mathrm{IU} / \mathrm{ml})$, streptomycin (10 $\mathrm{mg} / \mathrm{ml})$, insulin $(0.08 \mathrm{IU} / \mathrm{ml})$, prednisolon $(0.5 \mu \mathrm{g} / \mathrm{ml})$, glucagon $(0.008 \mu \mathrm{g} / \mathrm{ml})$ and plated in collagen-coated Petri dishes $(60 \mathrm{~mm})$, at a density of $2 \times 10^{6}$ cells/Petri dish. Hepatocytes were allowed to attach in a gassed atmosphere $\left(5 \% \mathrm{CO}_{2}\right)$ at $37^{\circ} \mathrm{C}$ for $2 \mathrm{~h}$.

After the establishment of monolayers, the medium was removed and replaced with fresh medium containing dissolved acetaminophen at concentrations of $1,2.5,5,10$ or $20 \mathrm{mmol} / \mathrm{l}$. Then the hepatocytes were incubated for appropriate time-period, mostly for $24 \mathrm{~h}$. After incubation, the medium was collected for required biochemical assays and cells were harvested or sonicated.

\section{Biochemical assays}

Acetaminophen toxicity was determined by lactate dehydrogenase activity (LDH) in the culture medium using a commercial kit from Diagnostic Systems (Germany). The functional capacity of cultured hepatocytes was evaluated by the amount of albumin secreted into the culture medium during incubation period using commercial ELISA kit from Bethyl Lab. Inc., (USA).

After cell lysis in freezer $\left(-80^{\circ} \mathrm{C}, 10 \mathrm{~min}\right)$ and harvesting of hepatocytes, antioxidative status of hepatocytes was determined by the measurement of glutathione content. Reduced and oxidized form of glutathione were analyzed by reverse-phase highperformance liquid chromatography (Shimadzu, Japan) using method of Hissin and Hilf (1976) modified by Kand'ár et al. (2007). The separation was performed on reverse-phase column Discovery C18, $15 \mathrm{~cm} \mathrm{x} 4 \mathrm{~mm}$, $5 \mu \mathrm{m}$ (Supelco, USA) followed by fluorometric detection (excitation wavelength $350 \mathrm{~nm}$, emission wavelength $420 \mathrm{~nm}$ ). The CSW32 program (DataApex, Czech Republic) was used for collecting and processing of the chromatographic data.

\section{WST-1 assay}

Cell viability was also evaluated by the WST-1 assay (Roche, Germany). WST-1 assay measures the activity of intramitochondrial and extramitochondrial 


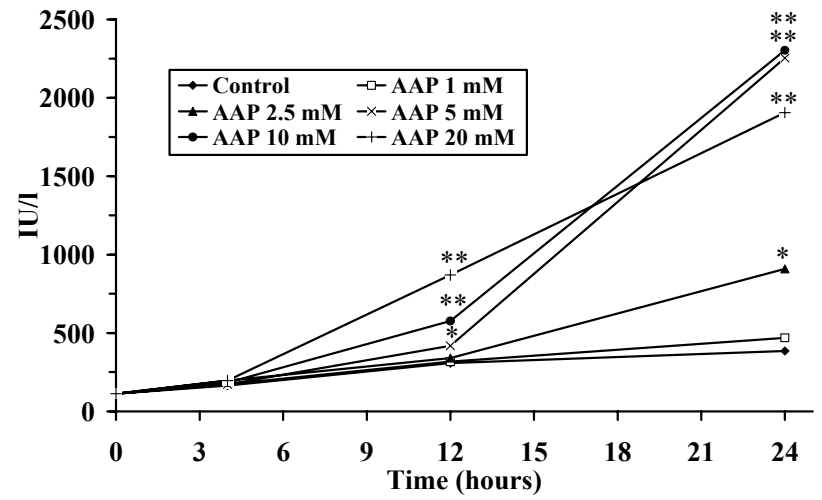

Fig. 1A. LDH activity in medium (time course $-4,12$ and $24 \mathrm{~h}$ ). The viability of cells was assayed by measurement of LDH activity at time points after treatment with different AAP concentration $(1,2.5,5,10$ and $20 \mathrm{mM})$. The results were expressed as mean \pm S.D. $(n=3)$ although only means are showed at the figure. $* p<0.05 ; * * p<0.01$ (compared to control at appropriate time period).

dehydrogenases. Briefly, tetrazolium salts are cleaved by dehydrogenases of viable cells to produce formazan and the change of absorbance is detected spectrophotometrically. Dehydrogenase activity was assayed in collagen-coated 96 well-plates (density of $3.10^{4}$ cells/well). At required time, the medium was removed and the WST-1 reagent (diluted 1:10 in PBS) was added. The cells were incubated in a gassed atmosphere (5\% $\mathrm{CO}_{2}$ ) for $60 \mathrm{~min}$. The changes in absorbance were measured using a microtiter plate reader TECAN Infinite M200 (Austria) at wavelength $440 \mathrm{~nm}$.

\section{Glutathione reductase assay}

Glutathione reductase (GR) activity was assayed by the method described by Carlberg and Mannervik (1975). The cells were sonicated by Bandelin Sonopuls sonicator (Germany) and the lysates were centrifuged $\left(4{ }^{\circ} \mathrm{C}, 10 \mathrm{~min}, 8000 \mathrm{~g}\right)$. Glutathione reductase activity in supernatants was estimated by monitoring of NADPH decrease by $340 \mathrm{~nm}$ for $7 \mathrm{~min}$ on microtiter plate reader spectrophotometrically and was expressed as units of enzyme per mg protein. The protein concentration was assayed according to Bradford (1976).

\section{Detection of reactive oxygen intermediates}

The production of reactive oxygen species (ROS) was evaluated using 5- and 6-chloromethyl-2',7'dichlorodihydrofluorescein diacetate $\left(\mathrm{CM}-\mathrm{H}_{2} \mathrm{DCFDA}\right.$; Molecular Probes, USA). CM- $\mathrm{H}_{2}$ DCFDA is nonfluorescent until hydrolyzed by esterases and oxidized by ROS in cells. After incubation, the cells were rinsed in phosphate-buffered saline (PBS) and consequently loaded

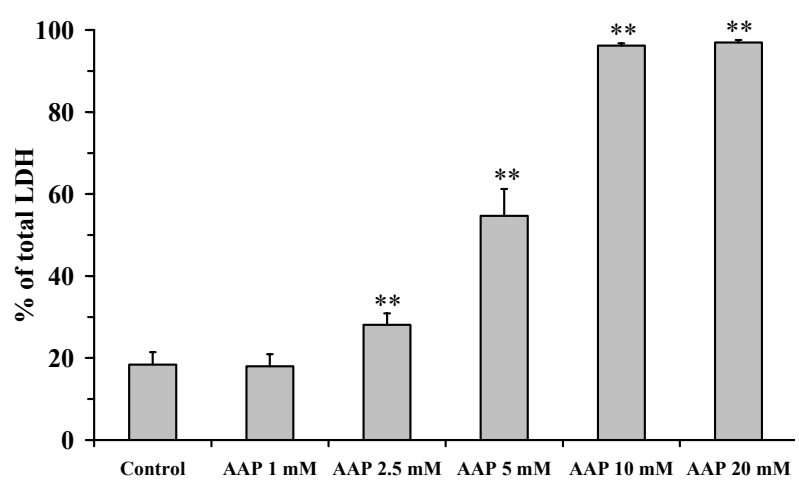

Fig. 1B. LDH leakage. The effect of AAP treatment $(1,2.5,5,10$ and $20 \mathrm{mM}$ ) on LDH leakage was assayed in hepatocytes after $24 \mathrm{~h}$. The results are expressed as mean \pm S.D. $(n=4)$. $* * \mathrm{p}<0.01$ (compared to control).

by $1 \mu \mathrm{M} \mathrm{CM}-\mathrm{H}_{2}$ DCFDA for $45 \mathrm{~min}$. The increase of fluorescence intensity was monitored in thermostated fluorescence plate reader TECAN Infinite M200 (Austria) for 1 hour using an excitation and emission wavelength 485 and $535 \mathrm{~nm}$, respectively. For better comparison of several samples in which big variation in the density of attached cells may occur, the results have been expressed as a ratio of the change in fluorescence intensity at the end and at the start of measurement.

\section{Statistical analysis}

Experiments were repeated at least three times using different hepatocyte preparations. The results are expressed as mean $\pm \mathrm{SD}$. After testing of normality, the statistical significance was analyzed using one-way ANOVA test followed by Dunnett's post hoc test for comparison between control group and the others. (GraphPad Prism 4.03 for Windows, GraphPad Software, USA). $\mathrm{p}<0.05$ was considered as significant.

\section{Results}

We examined the toxicity of acetaminophen in cultured rat hepatocytes treated with various concentrations of AAP $(1,2.5,5,10$ and $20 \mathrm{mM})$. We used LDH assay and WST-1 test to determine the cell viability. LDH activity in medium (Fig. 1A) increased significantly in three highest concentrations of AAP till $12 \mathrm{~h}$ of incubation; whereas no difference in LDH activity (compared to control group) was found after $4 \mathrm{~h}$ of incubation with AAP. The LDH activity in medium was increased after $24 \mathrm{~h}$ according to AAP concentration in a dose-dependent manner. However, the medium LDH activity in cells treated with $20 \mathrm{mM}$ AAP was lower in 


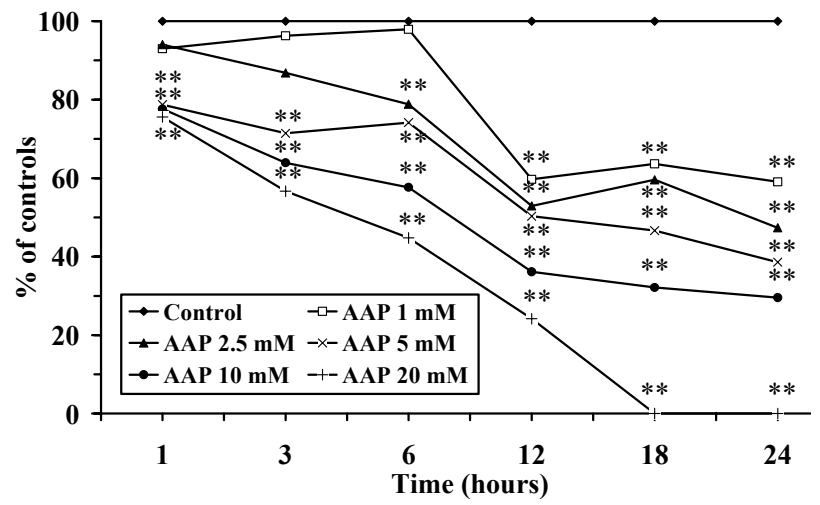

Fig. 2. WST-1 test (time course - 1, 3, 6, 12, 18 and 24 h). Cell viability was assayed by detection of cellular dehydrogenase activity. After AAP treatment $(1,2.5,5,10$ and $20 \mathrm{mM})$, hepatocytes were incubated with WST-1 cell proliferation reagent and the increase of absorbance $(\lambda=440 \mathrm{~nm})$ was detected during 1 hour. The results were expressed as means $(n=8)$ in percents of control signal. $* * p<0.01$ (compared to control at appropriate time period).

comparison with those exposed to 5 or 10 mM AAP. As results from $\mathrm{LDH}$ leakage in cells treated in $20 \mathrm{mM}$ AAP (Fig. 1B), the decrease of LDH activity found in medium in $20 \mathrm{mM}$ AAP is probably caused by total impairment of the enzyme. LDH leakage at $24 \mathrm{~h}$ was increased proportionally to AAP dose, although $1 \mathrm{mM}$ AAP seems to have no effect on LDH leakage.

WST-1 test evaluates the overall activity of cellular dehydrogenases. We used WST-1 at following time points of incubation - 1, 3, 6, 12, 18 and $24 \mathrm{~h}$ (Fig. 2). The enzyme activities in cells treated with 5, 10 and $20 \mathrm{mM}$ AAP were significantly reduced to less than $80 \%$ of control already during the first hour. After $12 \mathrm{~h}$ of incubation, all acetaminophen concentrations caused decrease in the activity of dehydrogenases - from $60 \%$ of controls in $1 \mathrm{mM}$ up to $24 \%$ of controls in $20 \mathrm{mM}$ AAP, respectively. Interestingly, no enzyme activity was found in cells treated with $20 \mathrm{mM}$ AAP after $18 \mathrm{~h}$ of incubation. The other doses of AAP caused further decline of the enzyme activity in dose-dependent manner.

For evaluation of functional capacity of hepatocytes, we used the analysis of albumin synthesis within $24 \mathrm{~h}$ of incubation. Figure 3 depicts the decrease in albumin production in AAP treated cells. Albumin production was reduced proportionally to AAP dose (5, $10,20 \mathrm{mM}$ AAP - to 52, 37 and $10 \%$ of control values, respectively). The levels of glutathione were assessed only after $24 \mathrm{~h}$ of incubation. As expected, the results showed total disappearance of reduced form of glutathione. GSH levels were detectable only in controls, $62.9 \pm 3.8 \mu \mathrm{M}$ and in $1 \mathrm{mM}$ AAP, $41.29 \pm 2.8 \mu \mathrm{M}(\mathrm{p}<0.01)$ $(n=6)$. The oxidized form, glutathione disulfide (GSSG),

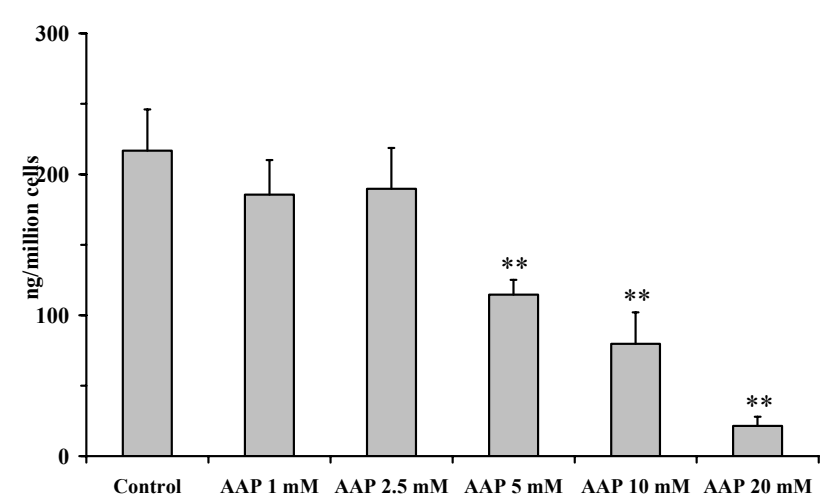

Fig. 3. Albumin production. The effect of AAP treatment $(1,2.5$, 5,10 and $20 \mathrm{mM}$ ) on hepatocytes albumin production was measured after $24 \mathrm{~h}$. Results are expressed as mean \pm S.D. $(\mathrm{n}=4) .{ }^{* *} \mathrm{p}<0.01$ (compared to control).

wasfound in all cells. However, the decrease of GSSG levels regarding concentration was also observed. The GSSG levels in controls, $1,2.5$, and $5 \mathrm{mM}$ AAP were: $5.9 \pm 1.7,5.54 \pm 1.1,1.5 \pm 0.3(\mathrm{p}<0.01)$ and $0.48 \pm 0.1 \mu \mathrm{M}$ $(\mathrm{p}<0.01)$, respectively. In hepatocytes incubated with 10 and $20 \mathrm{mM}$ AAP, GSSG levels were similar to $5 \mathrm{mM}$ AAP.

For better description of intracellular oxidative state, ROS production and activity of glutathione reductase were assayed. ROS production was evaluated at 3, 12 and $24 \mathrm{~h}$. As shown in Table 1, a significant occurrence of ROS was found in cells treated with 10 and $20 \mathrm{mM}$ AAP after $3 \mathrm{~h}$ of incubation. At 12 and $24 \mathrm{~h}$ time points, significant increase was identified in all groups except $1 \mathrm{mM}$ AAP. The $12 \mathrm{~h}$ incubation with AAP caused dose-dependent increase of ROS production -2.5 , 5, 10 and $20 \mathrm{mM}$ AAP, increased to $200 \%, 410 \%$, $490 \%$ and $770 \%$ of controls, respectively. After $24 \mathrm{~h}$, the increase was $0 \%, 87 \%, 490 \%$ and $400 \%$, respectively. Figure 4 shows the influence of incubation time and AAP concentration on glutathione reductase activity. GR activity was already reduced after $3 \mathrm{~h}$ in all of cells in comparison to control. In addition, there was a trend of dose-dependent reduction in GR activity. After $24 \mathrm{~h}$, the resulting activities were in control and 1, 2.5, 5, 10 and $20 \mathrm{mM}$ AAP, $56.5 \pm 1.8,52.2 \pm 3.4,49.5 \pm 1.0$, $44.5 \pm 1.7, \quad 34.9 \pm 4.5$ and $21.8 \pm 0.7 \mathrm{U} / \mathrm{mg}$ protein, respectively.

\section{Discussion}

Acetaminophen is a well-known hepatotoxin whose toxic action is highly dependent on its dose. In our study, rat hepatocytes in primary culture were used for estimation of AAP toxicity. Rat hepatocytes are much 
Table 1. Time course of ROS production in cultured rat hepatocytes.

\begin{tabular}{|c|c|c|c|}
\hline & 3 hours & 12 hours & 24 hours \\
\hline control & $90.2 \pm 5.7 \%$ & $24.7 \pm 9.6 \%$ & $35.5 \pm 9.3 \%$ \\
\hline$A A P 1 \mathrm{mM}$ & $137.0 \pm 54.9 \%$ & $45.1 \pm 6.3 \%$ & $22.2 \pm 3.6 \%$ \\
\hline (ratio to control) & $(1.51)$ & $(1.82)$ & $(0.63)$ \\
\hline$A A P 2.5 \mathrm{mM}$ & $178.8 \pm 39.6 \% * *$ & $74.3 \pm 21.2 \%$ & $35.3 \pm 16.0 \%$ \\
\hline (ratio to control) & $(1.98)$ & $(3.00)$ & $(1.00)$ \\
\hline$A A P 5 \mathrm{mM}$ & $147.0 \pm 32.5 \%$ & $126.2 \pm 47.1 \% * *$ & $66.7 \pm 12.9 \% *$ \\
\hline (ratio to control) & $(1.63)$ & $(5.11)$ & $(1.88)$ \\
\hline$A A P 10 \mathrm{mM}$ & $189.3 \pm 35.1 \% * *$ & $146.1 \pm 30.4 \% * *$ & $211.4 \pm 9.4 \% * *$ \\
\hline (ratio to control) & $(2.10)$ & $(5.91)$ & $(5.96)$ \\
\hline$A A P 20 \mathrm{mM}$ & $177.4 \pm 16.2 \% * *$ & $216.6 \pm 19.1 \% * *$ & $178.4 \pm 19.7 \% * *$ \\
\hline (ratio to control) & $(1.97)$ & $(8.76)$ & $(5.03)$ \\
\hline
\end{tabular}

After removal of the cell culture medium, cells were washed two times in PBS and DCFDA solution ( $1 \mu \mathrm{M}$, in PBS) was added. Hepatocytes were loaded for 45 min and then the solution was removed and PBS was added again. The increase of fluorescence was monitored for $1 \mathrm{~h}$ and the results are expressed as a percent ratio of difference between $0 \mathrm{~h}$ and $1 \mathrm{~h}$ and the fluorescence intensity at $0 \mathrm{~h}$. In addition, the ratio of signal of AAP-treated cells and control is given in brackets. The results of fluorescence increase are expressed as mean \pm S.D. $(n=4) . * p<0.05 ; * * p<0.01$ (compared to control at appropriate time period).

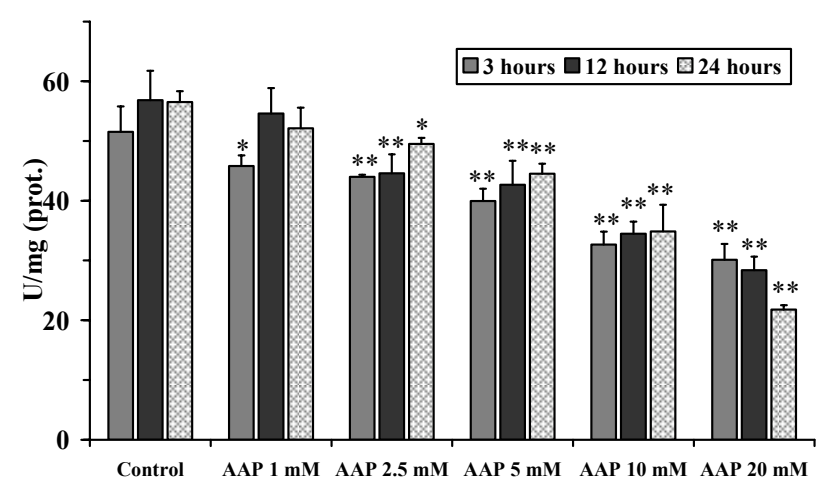

Fig. 4. Activity of glutathione reductase (time course $-3,12$ and $24 \mathrm{~h})$. AAP treated cells $(1,2.5,5,10$ and $20 \mathrm{mM})$ were sonicated and then GR activity was assayed in cell lysates. The activity of glutathione reductase was measured as decrease of NADPH absorbance at $\lambda=340 \mathrm{~nm}$ and expressed as Unit of enzyme activity per $\mathrm{mg}$ of protein ( $1 \mathrm{U}$ was defined as nmol of GSSG reduced per minute, using a molar extinction coefficient of $6.22 \times 10^{3}$ for NADPH). The results are expressed as mean \pm S.D. $(n=4)$. $* p<0.05 ; * * p<0.01$ (compared to control at appropriate time period).

more resistant to toxic action of acetaminophen, compared to mice or hamsters (Mitchell et al. 1973a, Tee et al. 1987). Since mouse hepatocytes have been used in most of studies interested in AAP toxicity, we decided to use rat hepatocytes where higher resistance was expected and proved in comparison with mice.

Hepatocytes were treated with different concentrations of AAP for various time periods and the changes in viability and cellular oxidative state were measured. Viability of cells was estimated by two different methods. The first method is commonly used assay of extracellular LDH activity and LDH leakage. The second assay is WST-1 test evaluating the activity of intra- and extramitochondrial dehydrogenases. Results obtained by both of these tests show a decline in cell viability detectable at $12 \mathrm{~h}$ of incubation. However, the LDH test did not show any changes of viability at $4 \mathrm{~h}$ of incubation. The WST-1 is a more sensitive assay that provided information about the decrease of enzyme activity in hepatocytes already after 1 hour of incubation. Moreover, the significant changes of enzyme activity in cells exposed to $1 \mathrm{mM}$ AAP are apparent in WST-1 after $12 \mathrm{~h}$, although LDH tests show no difference even after $24 \mathrm{~h}$. In addition, our WST-1 results documented that there is no dehydrogenase activity detectable in the cells treated with AAP $20 \mathrm{mM}$ for $18 \mathrm{~h}$. The comparison of both of tests is well consistent with recently published findings, where WST-1 test reflected the changes in viability of hepatocytes more precisely and earlier compared to LDH testing (Kikkawa et al. 2005).

We have monitored the production of reactive oxygen species for evaluation of oxidative stress. We have used the fluorimetric method based on the change in fluorescence intensity of intracellular probe, DCFDA, after oxidation. As the results show, the increase of fluorescence intensity present in all time points is strictly dose-dependent. The enhanced level of fluorescence in all of groups, including control, at $3 \mathrm{~h}$ of incubation may be detected due to higher oxidative stress linked to 
hepatocyte isolation. Therefore, we decided to express these data as a ratio between fluorescence of AAP-treated cells and controls, where the effect of enhanced levels of fluorescence in controls is eliminated. We have shown that $1 \mathrm{mM}$ AAP exerts mild influence on ROS production. The other AAP doses caused enhanced production of ROS. In addition, we have detected repeatedly high ROS levels in cells treated with $20 \mathrm{mM}$ and $10 \mathrm{mM} \mathrm{AAP}$ at $24 \mathrm{~h}$, although cell viability was highly decreased or even lost at this time interval. This finding is in good accordance with the results in mouse hepatocytes published recently (Bajt et al. 2004). Since a number of various compounds is able to react with DCFDA, the fluorescence signal in dead cells may be caused by reaction of the probe with stable compounds still persisting in dead cells (Halliwell and Whiteman 2004). There are only few reports using DCFDA for monitoring the implication of ROS in AAP toxicity (Bajt et al. 2004, Reid et al. 2005). Thus, it is quite difficult to compare our results with the others; especially, if we used rat hepatocytes in contrast to other researchers using mouse hepatocytes.

Glutathione reductase is an enzyme playing essential role in antioxidant defense. The GR function is to reduce the oxidized disulfide form of glutathione back to the reduced one. We have found that the activity of glutathione reductase is diminished in cells treated by most of AAP concentrations; GR activity has not been decreased in AAP $1 \mathrm{mM}$ treated cells. These results are in good accordance with findings published recently by Zhu and Lei (2006). These authors studied the influence of AAP concentration on two groups of mice knockout in glutathione metabolism-related enzymes; as a control group, they used wild-type mouse hepatocytes. They found the decrease in glutathione reductase activity, as well as in thioredoxin reductase activity after treatment of cells with acetaminophen, but the explanation of decrease of enzyme activities has not been given.

Once the GSH stores are exhausted in acetaminophen-induced injury of hepatocytes, NAPQI binds to a number of compounds, especially to $\mathrm{SH}$ moieties of proteins and the NAPQI adducts are then detected in cells. Many enzymes have been determined to react with NAPQI (James et al. 2003, Jaeschke and Bajt 2006), but in most of them no or very weak decrease of enzyme activity has been detected (Pumford et al. 1997). NAPQI adducts have also been proved in two enzymes contributing to glutathione metabolism - glutathione peroxidase and glutathione transferase (Cohen et al. 1997, Qiu et al. 1998). However, glutathione reductase has not been ever determined to react with NAPQI.

Glutathione reductase has been shown to be quite sensitive to oxidative stress. The decrease of enzyme activity was described following the reaction with products of lipoperoxidation, especially with 4hydroxynonenal (Vander Jagt et al. 1997). On the other hand, the influence of hydrogen peroxide on GR activity has also been studied, but no decrease in GR activity has been found (Vessey and Lee 1993). Therefore, the decrease of glutathione reductase activity could be explained by above described reason.

We studied the effect of acetaminophen treatment in cultured rat hepatocytes. Several methods were used to detect changes in oxidative status, viability and functional capacity of cells regarding dose and time interval of AAP treatment. The results show apparent relation of dose and toxic action of AAP. The treatment with $1 \mathrm{mM}$ AAP did not cause almost any significant changes after $24 \mathrm{~h}$ of incubation (except of WST-1 test and GR). On the other hand, the highest AAP dose $(20 \mathrm{mM})$ caused very intensive damage of cells even earlier than after $24 \mathrm{~h}$. Therefore, an optimal acetaminophen dose, which is recommended to be used for subsequent evaluation of AAP acting, eventually study of hepatoprotective substances in AAP toxicity (e.g. S-adenosylmethionin, N-acetylcysteine) (Kučera et al. 2006), seems to be $5 \mathrm{mM}$ AAP in cultured rat hepatocytes, especially when incubated for $24 \mathrm{~h}$.

\section{Conflict of Interest}

There is no conflict of interest.

\section{Acknowledgements}

This work was supported by grants MSM0021620820, GAUK 90/2006 and MSM0021627502.

\footnotetext{
Abbreviations

AAP - acetaminophen; DCFDA - dichlorodihydrofluorescein diacetate; GSSG - glutathione disulfide; GSH - glutathione (reduced form); GR - glutathione reductase; LDH - lactate dehydrogenase; NADPH - nicotinamide adenine dinucleotide phosphate; NAPQI - N-acetyl-pbenzoquinone imine; PBS - phosphate buffered saline; ROS - reactive oxygen species.
} 


\section{References}

BAJT ML, KNIGHT TR, LEMASTERS JJ, JAESCHKE H: Acetaminophen-induced oxidant stress and cell injury in cultured mouse hepatocytes: protection by N-acetyl cysteine. Toxicol Sci 80: 343-349, 2004.

BERRY M, EDWARDS A, BARRITT G: High-yield preparation of isolated hepatocytes from rat liver. In: Isolated Hepatocytes Preparation, Properties and Application, R BURDON, P VAN KNIPPENBERG (eds), Elsevier, New York, 1991, pp 15-81.

BRADFORD MM: A rapid and sensitive method for the quantitation of microgram quantities of protein utilizing the principle of protein-dye binding. Anal Biochem 72: 248-254, 1976.

CARLBERG I, MANNERVIK B: Purification and characterization of the flavoenzyme glutathione reductase from rat liver. J Biol Chem 250: 5475-5480, 1975.

COHEN SD, PUMFORD NR, KHAIRALLAH EA, BOEKELHEIDE K, POHL LR, AMOUZADEH HR, HINSON JA: Selective protein covalent binding and target organ toxicity. Toxicol Appl Pharmacol 143: 1-12, 1997.

HALLIWELL B, WHITEMAN M: Measuring reactive species and oxidative damage in vivo and in cell culture: how should you do it and what do the results mean? Br J Pharmacol 142: 231-255, 2004.

HISSIN PJ, HILF R: A fluorometric method for determination of oxidized and reduced glutathione in tissues. Anal Biochem 74: 214-226, 1976.

JAESCHKE H, BAJT ML: Intracellular signaling mechanisms of acetaminophen-induced liver cell death. Toxicol Sci 89: $31-41,2006$.

JAESCHKE H, KNIGHT TR, BAJT ML: The role of oxidant stress and reactive nitrogen species in acetaminophen hepatotoxicity. Toxicol Lett 144: 279-288, 2003.

JAMES LP, MAYEUX PR, HINSON JA: Acetaminophen-induced hepatotoxicity. Drug Metab Dispos 31: 1499-1506, 2003.

JOLLOW DJ, MITCHELL JR, POTTER WZ, DAVIS DC, GILLETTE JR, BRODIE BB: Acetaminophen-induced hepatic necrosis. II. Role of covalent binding in vivo. J Pharmacol Exp Ther 187: 195-202, 1973.

KANĎÁR R, ŽÁKOVÁ P, LOTKOVÁ H, KUČERA O, ČERVINKOVÁ Z: Determination of reduced and oxidized glutathione in biological samples using liquid chromatography with fluorimetric detection. $J$ Pharm Biomed Anal 12: 1382-1387, 2007.

KIKKAWA R, YAMAMOTO T, FUKUSHIMA T, YAMADA H, HORII I: Investigation of a hepatotoxicity screening system in primary cell cultures - "what biomarkers would need to be addressed to estimate toxicity in conventional and new approaches?" J Toxicol Sci 30: 61-72, 2005.

KNIGHT TR, KURTZ A, BAJT ML, HINSON JA, JAESCHKE H: Vascular and hepatocellular peroxynitrite formation during acetaminophen toxicity: role of mitochondrial oxidant stress. Toxicol Sci 62: 212-220, 2001.

KON K, KIM JS, JAESCHKE H, LEMASTERS JJ: Mitochondrial permeability transition in acetaminophen-induced necrosis and apoptosis of cultured mouse hepatocytes. Hepatology 40: 1170-1179, 2004.

KUČERA O, ČERVINKOVÁ Z, LOTKOVÁ H, KřIVÁKOVÁ P, ROUŠAR T, MUŽÁKOVÁ V, HÉŽOVÁ R, KANĎÁR R, RUDOLF E: Protective effect of S-adenosylmethionine against galactosamine-induced injury of rat hepatocytes in primary culture. Physiol Res 55: 551-560, 2006.

LEE WM: Drug-induced hepatotoxicity. N Engl J Med 349: 474-485, 2003.

MITCHELL JR, JOLLOW DJ, POTTER WZ, DAVIS DC, GILLETTE JR, BRODIE BB: Acetaminophen-induced hepatic necrosis. I. Role of drug metabolism. J Pharmacol Exp Ther 187: 185-194, $1973 \mathrm{a}$.

MITCHELL JR, JOLLOW DJ, POTTER WZ, GILLETTE JR, BRODIE BB: Acetaminophen-induced hepatic necrosis. IV. Protective role of glutathione. J Pharmacol Exp Ther 187: 211-217, $1973 \mathrm{~b}$.

PUMFORD NR, HALMES NC, MARTIN BM, COOK RJ, WAGNER C, HINSON JA: Covalent binding of acetaminophen to N-10-formyltetrahydrofolate dehydrogenase in mice. J Pharmacol Exp Ther 280: 501-505, 1997.

QIU Y, BENET LZ, BURLINGAME AL: Identification of the hepatic protein targets of reactive metabolites of acetaminophen in vivo in mice using two-dimensional gel electrophoresis and mass spectrometry. $\mathrm{J}$ Biol Chem 273: 17940-17953, 1998. 
REID AB, KURTEN RC, MCCULLOUGH SS, BROCK RW, HINSON JA: Mechanisms of acetaminophen-induced hepatotoxicity: role of oxidative stress and mitochondrial permeability transition in freshly isolated mouse hepatocytes. J Pharmacol Exp Ther 312: 509-516, 2005.

TEE LB, DAVIES DS, SEDDON CE, BOOBIS AR: Species differences in the hepatotoxicity of paracetamol are due to differences in the rate of conversion to its cytotoxic metabolite. Biochem Pharmacol 36: 1041-1052, 1987.

VANDER JAGT DL, HUNSAKER LA, VANDER JAGT TJ, GOMEZ MS, GONZALES DM, DECK LM, ROYER RE: Inactivation of glutathione reductase by 4-hydroxynonenal and other endogenous aldehydes. Biochem Pharmacol 53: 1133-1140, 1997.

VESSEY DA, LEE KH: Inactivation of enzymes of the glutathione antioxidant system by treatment of cultured human keratinocytes with peroxides. J Invest Dermatol 100: 829-833, 1993.

ZHU JH, LEI XG: Double null of selenium-glutathione peroxidase-1 and copper, zinc-superoxide dismutase enhances resistance of mouse primary hepatocytes to acetaminophen toxicity. Exp Biol Med (Maywood) 231: 545-552, 2006. 